УДК $358.1,355.69 / 357.321$

DOI: $10.33099 / 2707-1383-2020-38-4-92-99$

Тарасенко Л.П., старший науковий співробітник, філія Національного військово-історичного музею Украӥни - музею Ракетних військ стратегічного призначення

(м. Первомайськ Миколаӥвської обл., Украӥна)

\title{
МУЗЕЙ РАКЕТНИХ ВІЙСЬК СТРАТЕГІЧНОГО ПРИЗНАЧЕННЯ: ЕКСПОНАТИ РОЗСЕКРЕЧЕНИХ КОМПЛЕКСІВ
}

\begin{abstract}
Здійснено огляд та виклад історії нині розсекреченої, а раніше абсолютно невідомої військової автомобільної техніки. Подано опис агрегатів рухомих трунтових ракетних комплексів, які створювалися в умовах абсолютної таємності в закритих спеціальних конструкторських бюро і на численних підприємствах країни.

Ключові слова: Ракетні війська стратегічного призначення, бойове чергування, рухомий трунтовий ракетний комплекс, рухомий командний пункт, автономні машини бойового, технічного і побутового забезпечення особового складу стратегічних ракетних комплексів.
\end{abstract}

Колекцію унікальних експонатів музею Ракетних військ стратегічного призначення поповнила оригінальна ракетна техніка - автономні машини бойового, технічного і побутового забезпечення особового складу стратегічних ракетних комплексів, які здійснювали бойове чергування під час руху по грунтових дорогах за заданими маршрутами переміщення. Так, в одній із експозицій під відкритим небом музею РВСП тепер представлені агрегати рухомих грунтових ракетних комплексів (ПГРК): машини забезпечення бойового чергування (МОБДи)15В231, 15Т117, 15Т118, а також агрегати рухомого командного пункту ракетної дивізії (ПКП рд) 15В119 «Вибор»: 15B129, 15B133, 15B134, 15Н1061М (до речі, агрегати ПКП рд знаходилися на зберіганні в арсеналі ракетних військ «Михайльонки», а були передані вони з в/ч 43195 (37pд) м.Луцьк після іiї ліквідації). Давайте познайомимося 3 ними, здійснивши невеликий екскурс в історію.
В Ракетних військах стратегічного призначення завжди існувала прихована від сторонніх очей величезна армія спеціальної автотехніки. Її головним призначенням були забезпечення постійної бойової готовності ракетних комплексів, транспортування і установка частин балістичних ракет, обслуговування бойових і допоміжних машин та надання екіпажам гідних умов довгострокової служби «в чотирьох стінах» під час патрулювання і далеких походів рухомих стратегічних систем. Вони могли проходити по безлюдних районах 3 несприятливими кліматичними умовами при повній відсутності ремонтних баз, джерел електроенергії, водопостачання, об'єктів харчування та приміщень для розміщення та відпочинку особового складу, 3 яких формували колони машин забезпечення, що супроводжували ракетні системи. Такі машини застосовувалися також для забезпечення автономних бойових дій мобільних зенітних систем ППО, в берего- 
вих комплексах та інших військових частинах, розміщених в малонаселених районах. До типового набору такої техніки входили рухомі засоби забезпечення бойового чергування і охорони, пересувні їдальні та гуртожитки, майстерні різного профілю і електростанції тощо.

Формування строго засекреченого сектора військово-автомобільного комплексу почалося в перші повоєнні роки, коли Радянський Союз перебував в стадії «холодної війни». Надалі з появою надзвукової авіації, потужної ракетної і ядерної зброї, незважаючи на величезні організаційні, кадрові, технічні і технологічні проблеми, вся ця розгалужена і непомірно дорога строго засекречена система постійно приносила свої важливі плоди, набагато випереджаючи аналогічні цивільні галузі, які не отримували настільки ж щедрої державної підтримки. У роки глибокого військового протистояння секретність і цензура в цій області панували тотальні - від моменту прийняття рішення про початок проектування і до повної ліквідації машин. Після розпаду СРСР основна частка інформації та зображень військової автотехніки була розсекречена, але частина матеріалів взагалі знищено, і тому донині деякі відомості, характеристики, результати випробувань залишаються неповними або продовжують носити гриф «таємно».

Перші машини були створені на шасі МА3-543А 3 типовими кузовами-фургонами декількох видів і входили до складу рухомого ракетного комплексу $15 П 696$ на гусеничному ходу з балістичними ракетами середньої дальності РТ-15. Вперше вони з'явилися у складі колісних ОТРК «Темп-С» і СРК «Темп-2С», потім застосовувалися в ракетних комплексах «Піонер» i «Тополь», ЗРК С-300. Склад колон забезпечення, кількість машин і їх комплектація залежали від конкретного призначення, за- стосування, місця дислокації, кліматичних умов і кількості особового складу супроводжуваних систем озброєння. Вони створювали рухомі командні пункти, постійно супроводжували пускові установки під час їх бойового чергування. Всі агрегати забезпечували бойове застосування та експлуатацію в будь-який час року і доби при температурі навколишнього повітря від -50 до $+40^{\circ} \mathrm{C}$, відносній вологості повітря при температурі $25^{\circ} \mathrm{C}$ до $98 \%$; швидкості вітру біля землі до 20 м / сек, під час розгортання і згортання антен і до 25 м/сек під час експлуатації: в дощ, пил, туман, сніг; в умовах хімічної, бактеріологічної і радіоактивної зараженості місцевості.

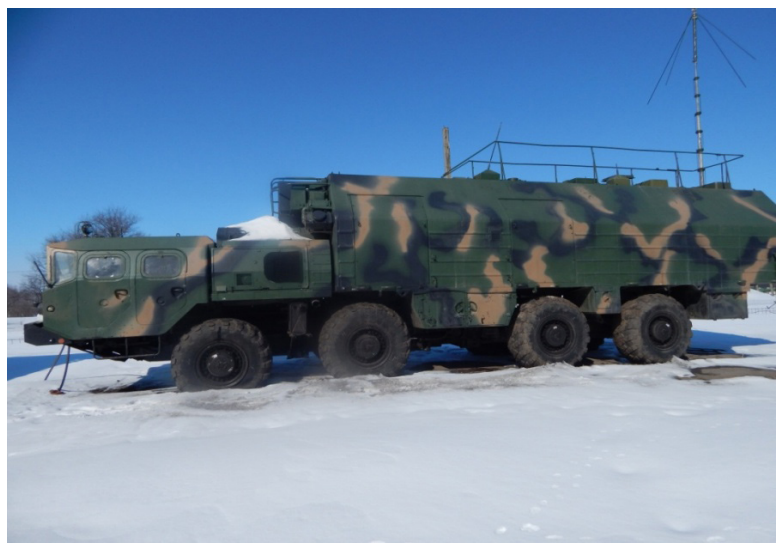

Агрегат 15В129. Машина бойового управління рухомого командного пункту ракетної дивізії, призначена для прийому і передачі по радіо бойових команд управління, а також у взаємодії з агрегатами 15В133, 15В134, 15B75 і М50 (Б-51) для організації та ведення оперативно-командного зв'язку з вищими ланками управління і об'єктами позиційного району.

Агрегат 15В129 змонтований на базі серійного автошасі МА3-543А і забезпечує:1) прийом сигналів централізованого бойового управління (ЦБУ), 2) прийом і передачу сигналів радіоканалів бойового управління (РБУ). Дальність зв'язку: в ДВ-СВ-діапазоні - до 150 км, в УКВ- діапазоні - до 45 км, 3) телефонний закри- 
тий оперативно-командний зв'язок (ОКЗ) 3 вищими ланками управління (ВЗУ) і позиційного району (ПР) спільно з агрегатами 15B133 і 15B134, 4) телекодовий закритий ОКЗ і з ВЗУ спільно з агрегатами 15В133, 15B134 і M50 (Б-51), 5) зв'язок по колоні на марші по радіостанції Р-123М в діапазоні частот 20-51.5 МГц. Дальність зв'язку 7 км в умовах рівнинної місцевості, 6) зв'язок між агрегатами комплексу на марші по радіостанціях Р-138 в діапазоні частот 76-93,95 МГц. Дальність зв'язку 3 км в умовах рівнинної місцевості, 7) зв'язок між агрегатами комплексу на позиції, 8) час розгортання агрегату на позиції - 20 хв без урахування розгортання КМП-2 і комплекту «Сосна» - M6В. Час згортання агрегату - 30 хв, 9) потужність, яку споживає агрегат на позиції, не більше 30 кВт, на марші - не більше 10кВт, 10) габаритні розміри агрегату: 14425x3250x4460мм, 11) маса укомплектованого агрегату з екіпажем не більше 40600 кг.

Кузов розділений перегородками на 5 відсіків: перший і другий (суміщені) відсік для апаратури 15Е621-1, обладнання САЕ, вироби 15E1155, обладнання життєзабезпечення і потреб особового складу агрегату; третій відсік - відсік апаратури 3АЗ і приймальної апаратури РБУ 15Е646-П-1 (15Е619,15Е646-П); четвертий відсік - операторський; п'ятий відсік тамбур. Апаратура і устаткування агрегату розташовано в спеціальному кузові, на його даху, в підкузовних ящиках і нішах, а також в кабінах автошасі МА3-543А.

Агрегат 15B133. Машина зв'язку (приймальна) рухомого командного пункту ракетної дивізії, є складовою частиною комплексу 15В119 і забезпечує спільно з агрегатами 15В129,15В134 організацію ведення ОКЗ. Призначений для бойового управління ракетними комплексами при виконанні ними бойового завдання

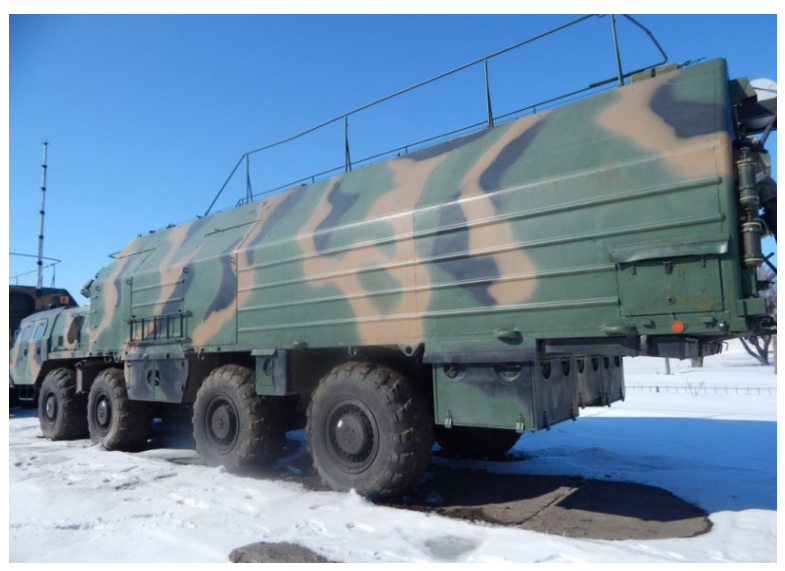

в режимах бойового чергування і здійснення маршу.

Агрегат 15В133 здійснює прийом інформації в КВ і УКВ діапазонах, а також прийом і передачу інформації в ДМВ діапазоні.

Габаритні розміри агрегату: довжина - 14425 мм, ширина - 3250 мм, висота - 4500 мм (при опущених антенах), висота - 5200 мм (при піднятих антенах на даху), маса укомплектованого агрегату з екіпажем не більше 40600 кг, прохідність агрегату по дорогах всіх категорій забезпечується 3 наступними максимальними швидкостями по шосе - 45 км / год, по грунтових дорогах - 25 км / год, розвіданою місцевістю - 15 км / год.

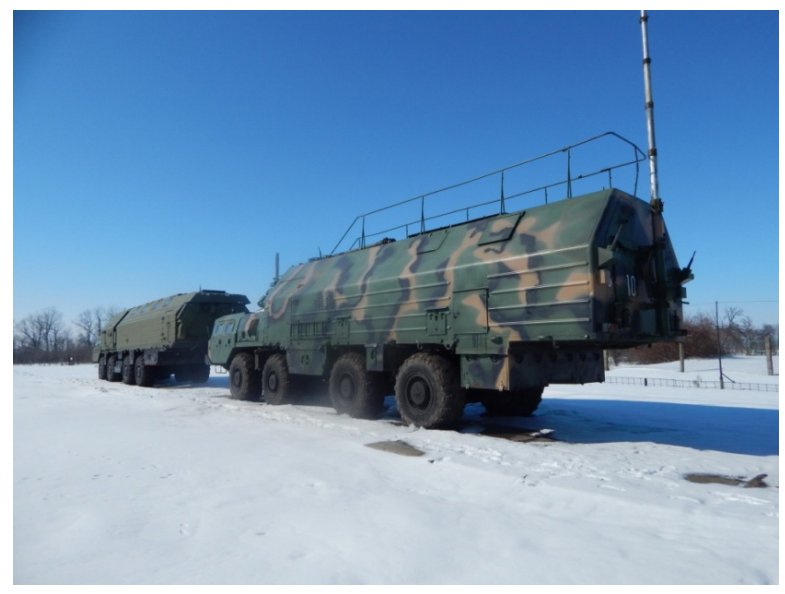

Агрегат 15В133 дозволяє долати брід глибиною не більше 0,6 м без прийняття додаткових заходів 3 відновлення бойової готовності. 
Апаратура й устаткування агрегату розташовуються в кузові, на його даху, в підкузовних ящиках і нішах, а також в кабінах автошасі MA3-543A.

Агрегат 15B134. Машина зв'язку, (передавальна) рухомого командного пункту ракетної дивізії є складовою частиною комплексу 15В119 «Вибор» і забезпечує передачу інформації при проведенні оперативно-командного зв 'язку з агрегату 15В129 і 15В133 з вищестоящими і підлеглими ланками управління. Агрегат 15B134 здійснює передачу інформації, яка транслюється 3 агрегатів 15B129 і 15В133 по одному каналу УКВ або одному каналу КВ - діапазону на позиції і одному каналу УКВ на марші.

Агрегат 15B134 змонтований на базі серійного автошасі МАЗ-543А і забезпечує наступні технічні характеристики: 1) передачу інформації в УКВ діапазоні; 2) передачу інформації в КВ діапазоні; 3) УКВ радіозв'язок по колоні на марші передається через радіостанцію Р-123М: дальність зв'язку на марші до 7 км; 4) УКВ радіозв'язок між агрегатами комплексу по радіостанціях P-138 дальність зв'язку на марші до 3 км; 5) зв'язок з агрегатами комплексу на позиції.

Габаритні розміри агрегату: довжина - 13950 мм;ширина - 3230 мм; висота — 4200 мм при опущених антенах і 5200 мм - при піднятих антенах на даху, маса укомплектованого агрегату з екіпажем не більше 40600 кг.

Особливе місце для нормального несення бойового чергування відводиться тиловому забезпеченню (ТО) Ракетних військ стратегічного призначення. До тилового забезпечення входить підготовка місця відпочинку чергової зміни, встановленого наказом командира, тобто територія, де перебувають на ній обладнання і засоби матеріального забезпечення, що створюють необхідні умови для своєчасного і повноцінного відпочинку особового складу чер- гових змін і розрахунків. Для ТО бойового чергування ракетних комплексів з самохідними пусковими установками ракети була створена машина забезпечення бойового чергування, яка оснащена спеціальним обладнанням і призначена для охорони, приготування їжі, організації харчування і відпочинку особового складу чергової зміни.

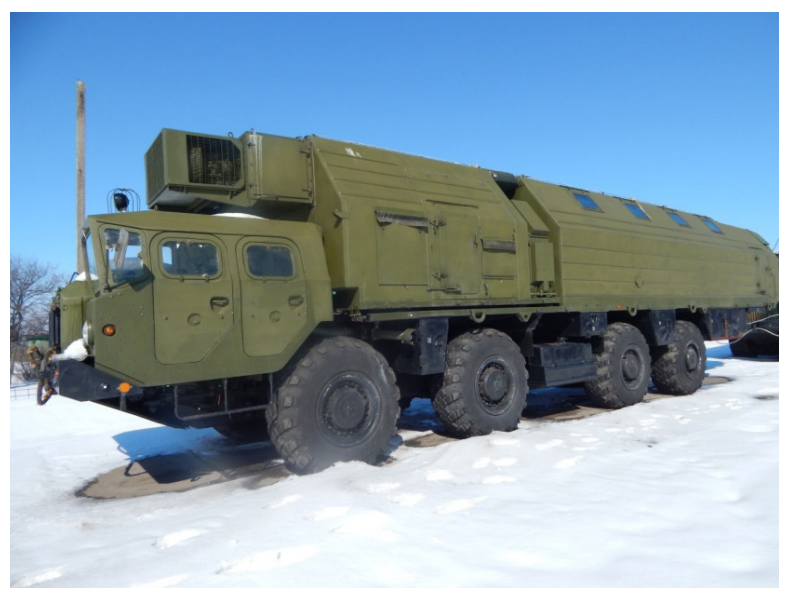

Агрегат 15В231. Машина забезпечення бойового чергування (МОБД 1, 2, 3, 4, 5 для ракетного комплексу «Тополь») - спеціальна машина, оснащена необхідним обладнанням і призначена для охорони, приготування їжі, організації харчування і відпочинку особового складу чергової зміни в польових умовах.

Для стійкого тилового забезпечення чергових сил в МОБД в період підготовки до заступання на бойове чергування створюються і постійно містяться запаси матеріальних засобів. Розміри запасів визначаються вимогами наказів міністра оборони. МОБД рухомих командних пунктів полку і дивізіонів, заправлені пальним і охолоджувальною рідиною, укомплектовані постільними речами, продуктами (крім тих, що швидко псуються) та іншим майном, розміщуються в обладнаних сховищах у готовності до виходу на польові позиції.

Розміри і обладнання агрегату розраховані на забезпечення життєдіяльності 10-ти осіб з особистими речами та зброєю. 
В агрегаті передбачені системи електропостачання, управління, зв'язку, мікроклімату, опалення, вентиляції, водопостачання, кухонно-складське і побутове обладнання.

Конструктивно агрегат складається з двох, не пов'язаних жорстко між собою, відсіків.

Перший відсік - дизельний. У дизельному відсіку розміщені два дизель- генератори АДА-30 потужністю 30 кВ. Між першим і другим відсіками розташований паливний бак з запасом палива 2398 л для АДА-30.

Другий відсік - основний, розділений перегородками на 7 відсіків різного цільового призначення - 2 відсіки використовуються для розміщення людей: чотирьохмісне купе для відпочинку особового складу і двомісне купе - для відпочинку начальника караулу і його помічника. Є купе-їдальня для прийому їжі особовим складом, (одночасно можуть приймати їжу 4 людини). Купе - їдальня обладнана одним складним спальним місцем для кухаря. У кухонному відсіку є плита для приготування їжі, чарунки для зберігання продуктів, холодильник, місце для зберігання посуду і їі миття.

Бойовий відсік оператора призначений для розміщення в ньому чергової зміни, тут розташований бойовий пост оператора і пост стрілка БПУ. У відсіку встановлена кінцева апаратура системи охорони, пульт оператора автономної пускової установки, сейф і піраміда для зброї. Над бойовим відсіком змонтована БПУ.

Середній відсік (тамбур) і бойової відсік оператора 3'єднані між собою коридором, який йде по всьому лівому борту від бойового відсіку і до купе-їдальні (за принципом коридору поїзда). В ньому розташований умивальник, відсіки для сушіння верхнього одягу і взуття. 3 коридору є входи через внутрішні зсувні двері в купе і відсік оператора, з тамбура в їдальню, з їдальні - в кухню. Тамбур обладнаний вхідними дверима.

Габаритні розміри: довжина 15700 мм, ширина - 3230 мм, висота 4415 мм,

Маса повністю спорядженого агрегату з екіпажем - 43500 кг.

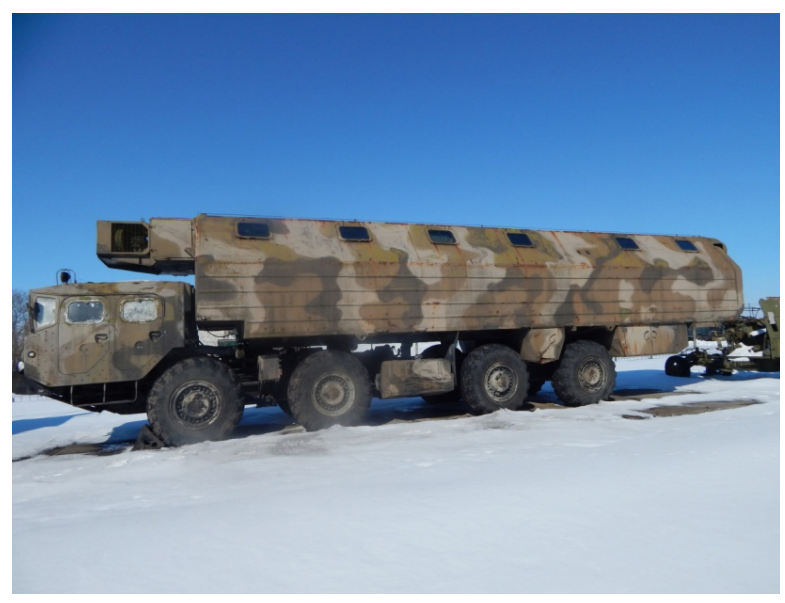

Агрегат 15T118. Машина забезпечення бойового чергування (МОБД-2) Машина-гуртожиток призначена для забезпечення життєдіяльності та відпочинку особового складу під час несення бойового чергування в польових умовах. Унікальний мобільний готель для тимчасового проживання особового складу розрахований на розміщення 24 осіб (6 купе по 4 людини) 3 особистими речами та зброєю.

В агрегаті передбачені системи електропостачання, оповіщення, зв'язку, мікроклімату, опалення, вентиляції, водопостачання, а також є сушарки для взуття і обмундирування.

Вага повністю спорядженого агрегату 3 водою в системі водопостачання (без особового складу) 36320 кг, довжина 15370 мм, ширина - 3240 мм, висота 3960 мм.

Автомобіль-гуртожиток 15T118, або «рухомий готель» для відпочинку і тимчасового групового проживання військо- 
вослужбовців у польових умовах був унікальним, оригінальним i незвичайним агрегатом РВСН. Його створювали для комплексу «Темп-2С», але згодом варіанти цієї машини надходили в інші ракетні й зенітні з'єднання. Їх оснащення розміщувалося в кузові з двома бічними вхідними дверима, власними системами електрообладнання, водопостачання, вентиляції, опалення та кондиціювання повітря. Уздовж всієї правої сторони кузова проходив коридор з заднім тамбуром, де знаходилися загальна роздягальня, умивальник, поздовжні підвісні полиці і ящики для білизни і системи зв'язку. 3 лівого боку знаходилися шість купе з речовими рундуками в нижніх ліжках. У кожному купе - тумбочка 3 настільною лампою, шафа 3 дзеркалом, електричний вентилятор, радіоприймач, внутрішній телефон і термометр. В деяких машинах була душова кабіна з баком на 300 літрів води.

Даний агрегат використовувався у військовій частині 33874 (19-я ракетна дивізія. м. Хмельницький) заводський № 11886683 дата випуску 29.03.1984 року підприємства П / с M-5271.

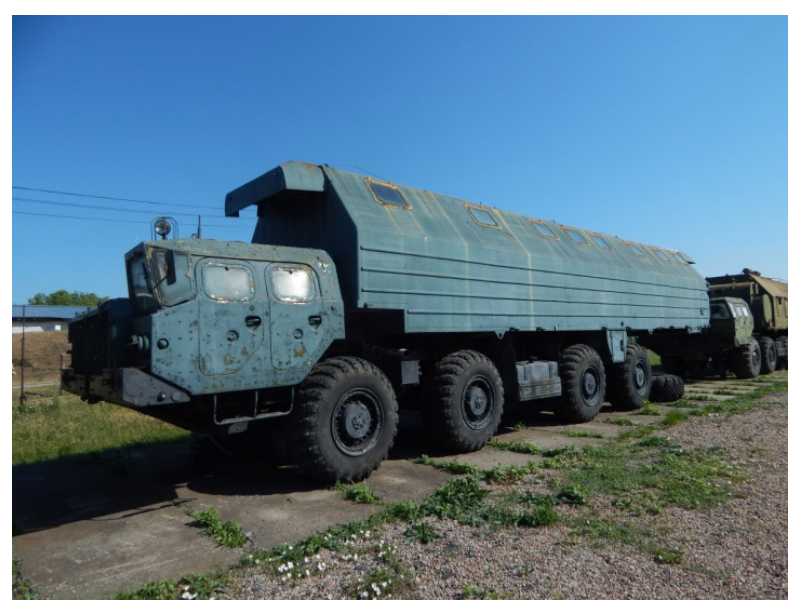

Агрегат 15T117. Машина забезпечення бойового чергування (МОБД-1). Машина-їдальня призначена для забезпечення життєдіяльності та відпочинку особового складу при несенні чергування в польових умовах, для зберігання запасів продовольства, приготування їжі та харчування.

Машина-їдальня розрахована для одночасного харчування 16 осіб.

До складу агрегату входять: колісне шасі високої прохідності, кузов встановлений на шасі, обладнання, змонтоване на шасі і в кузові.

Кузов являє собою суцільнометалеву зварену конструкцію, що складається з каркасу з основою, зовнішньої і внутрішньої обшивок, підлоги, щитів, дверей і люків. Зовнішня обшивка кузова виконана із сталевих листів товщиною 1 мм, внутрішня виконана панелями, склеєними 3 листової бакелітизованої фанери товщиною 5мм i декоративного пластику. У бічних стінах кузова - двоє зовнішніх одностулкових дверей і 16 вікон. У задній стінці кузова знаходяться одностулкові двері. Всі вікна 3 подвійним склінням, гумовими ущільнювачами і запорами. На вікнах встановлені світломаскувальних штори і захисні сітки від комах.

Усередині кузов розділений перегородками на відсіки різного цільового призначення. Починаючи від передньої стінки кузова, розташовані такі відсіки:

- передній службовий тамбур,

- купе на 4 спальних місця для персоналу,

- середній перехідний тамбур, який відкриває доступ до головного залу-їдальні для одночасного харчування 16 осіб, обладнаного 4 складними столами, стільцями, телевізором і радіоприймачем. Далі:

- відсік ЗІП,

- продовольчий склад,

- душ,

- варильне відділення з роздачею і мийкою,

- задній тамбур, поєднаний з роздягальнею. 
Їдальня може бути перетворена в залу для перегляду теле- і відеопрограм та прослуховування радіопередач.

3 кухонним відсіком суміщені душова кімната для персоналу та складське приміщення (продовольчий склад) 3 холодильником і шафами для зберігання 750 кг продуктів з розрахунку на 7 діб забезпечення. Задній тамбур з роздягальнею використовується для входу і виходу особового складу. В агрегаті передбачені системи електропостачання, управління, зв'язку, мікроклімату, опалення, вентиляції, водопостачання, оповіщення, кухонно-складського і побутового обладнання. Агрегат змонтований на колісному шасі МА3-543В (МА3-543М) підвищеної прохідності. Електроживлення всіх систем здійснювалося від промислової мережі змінного струму напругою 220 або 380 В, від рухомої електростанції або джерела постійного струму в 24-27 В.

Габаритні розміри машини (ДхШхВ) $15,365 \times 3,240 \times 4,436$ м (3 опущеною антеною). Запас питної води (возить) 2200 л.

Експлуатація: РК $15 П 642$ «Темп-2С», РК 15П645 «Піонер»,РК 15П645К «Піонер-К»,РК $15 П 653$ «Піонер-УТТХ», РК $15 П 656$ «Горн»,РК 15П158.1 «Тополь-Т», ПКП рд 15В119 «Вибір».

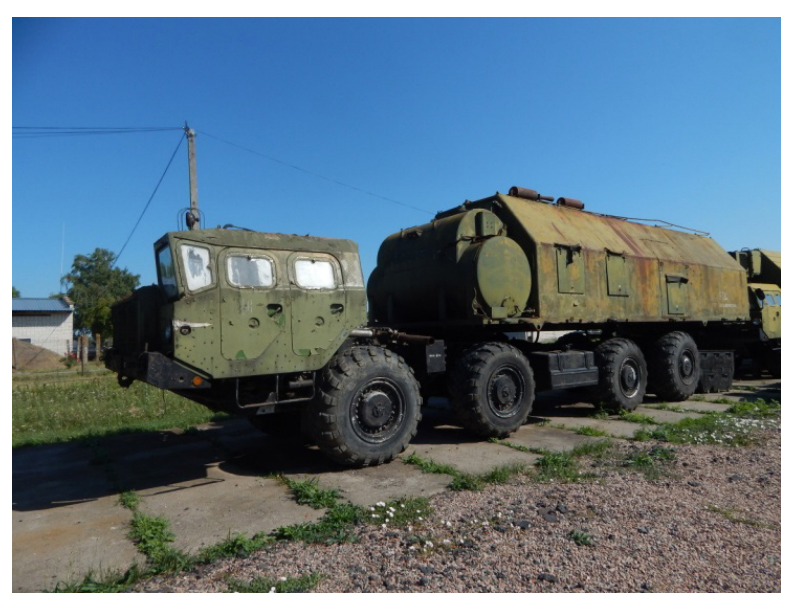

Агрегат 15H1061М. Машина дизель - електростанція - багатоцільова рухома автономна електростанція $\mathrm{PBCH}$ на шасі МАЗ-543В. Електростанція забезпечувалася зсунутим до задньої частини шасі глухим кузовом 2213, в якому знаходилися чотири дизель-електричних агрегати АД30-Т400-2Р з генераторами ДГФ82$4 К$, $з$ яких зазвичай працювали тільки одна, дві або три установки, а четверта була запасною. Вони виробляли змінний трифазний струм частотою 50 Гц і напругою 400 В для живлення всіх споживачів мобільних систем озброєння в будь-яких метрологічних умовах і температурі. Номінальна потужність одного агрегату становила 30 кВт, при одночасній роботі з другим і третім дизель-генератором сумарна потужність зростала до 50 і 84 кВт відповідно. При тривалій стаціонарній роботі на даху встановлювалася вертикальна 4-метрова вихлопна труба. Між моторним відсіком шасі і кузовом містилася циліндрична цистерна на 4300 л дизельного палива для електроагрегатів. Габаритні розміри станції в транспортному положенні - 14060x3240x4415 мм. Повна маса - 41,0 т. Тривалість безперервної роботи без будь-якого обслуговування 250 годин, без дозаправки - 168 годин, або 7 діб.

У варіанті ПАО-1 (пересувного агрегату освітлення) 3 комплектом різних прожекторів, кабельних котушок, настановних пристосувань і засобів підзарядки акумуляторів переносних ліхтарів електростанція була пересувним агрегатом освітлення.

Отже, ефективна автомобільна техніка 3 передовими системами озброєння, представлена в експозиції, зокрема, агрегати рухомих грунтових ракетних комплексів, які свого часу відігравали важливу роль в протистоянні розв'язанню Третьої світової війни, послуживши зрозумілим аргументом стримування гонки озброєння і мирного співіснування, тепер - експонати музею. 


\section{СПИСОК ВИКОРИСТАНИХ ДЖЕРЕЛ І ЛІТЕРАТУРИ}

1. Агрегат 15Т118. Формуляр (15Т118ФО). Завод. № 11886683.1976 р. 147 с.

2. Агрегат 15В129. Технічний опис (15В129TО). ШІ2.000.219ТО. Видання перше. 1987 р. 128 с. Введене в дію за вказівкою командира в/ч 08310 № 5004 від 13 липня 1984 р. MO CPCP.

3. Агрегат 15В133. Технічний опис (15В133ТО). ШІ2.000.220ТО. Видання перше. 1987 р. 96 с. Введене в дію за вказівкою командира в/ч 08310 № 5004 від 13 липня 1984 р. MO CPCP.

4. Агрегат 15В134. Технічний опис (15В134ТО). ШІ2.000.221ТО. Видання перше. 1987 р. 108 с. Введене в дію за вказівкою командира в/ч 08310 № 5004 від 13 липня 1984 р. MO CPCP.

5. Енциклопедія Ракетних військ стратегічного призначення / Під заг.ред. д-ра воєн. наук, проф. Н.Е. Соловцова. М.: РВСП; Білгород: Білгородська обласна друкарня, 2009. 860 с.

6. Стратегічні ядерні сили. Енциклопедія XXI с.Том I / Під заг. ред. МО РФ Маршала РФ I. Сергеєва. М.: Видавничий дім «Зброя і технології». 2000. 511 с.

7. Секретные автомобили Советской Армии. Кочнев Е.Д. URL: https://tech.wikireading.ru/ 1091.

Tarasenko L.P., senior researcher of the branch of the National Military History Museum of Ukraine - the Museum of Strategic Missile Forces (Pervomaisk, Mykolaiv region)

\section{SUPPORT FACILITIES OF MISSILE SYSTEMS OF LAND-BASED STRATEGIC NUCLEAR FORCES IN THE EXHIBITION OF THE MUSEUM}

An overview and an attempt to present in detail the history of the now declassified, and previously completely unknown military vehicles was made. The description of units of mobile ground-based missile systems, which were created in conditions of absolute secrecy in closed special design bureaus and at numerous enterprises of the country, is given.

Keywords: Strategic missile forces, combat duty, mobile ground missile system, mobile command post, autonomous vehicles for combat, technical and household support of strategic missile personnel. 